\title{
PERUBAHAN STRUKTUR KETERKAITAN \\ SEKTOR PERIKANAN DALAM PEREKONOMIAN INDONESIA: Analisis Multiplier Product Matrix(MPM), Menggunakan Soni's Technique
}

\author{
Tajerin $^{1}$
}

\begin{abstract}
ABSTRAK
Kajian ini bertujuan menganalisis perubahan struktur keterkaitan sektor perikanan dalam perekonomian Indonesia. Data yang digunakan merupakan data sekunder yang diperoleh dari buku Tabel Input Output (I-O) Tahun 1990, 1995 dan 2000 untuk transaksi domestik dan transaksi total atas dasar harga produsen. Analisis data dilakukan dengan pendekatan model I-O melalui perolehan nilai Multiplier Product Matrix (MPM) dari hasil perhitungan menggunakan Soni's Technique. Hasil analisis menujukkan bahwa berdasarkan kecenderungan rata-rata ketinggian nilai MPM sektor perikanan pada "economic landscape" transaksi domestik yang meningkat selama periode analisis (1990-2000), diperoleh indikasi secara struktural keterkaitan sektor perikanan mengalami perubahan yang meningkat dengan sektor-sektor lainnya dalam perekonomian Indonesia. Namun sebagaimana ditunjukkan oleh adanya perbedaan ratarata ketinggian MPM yang semakin besar antara transaksi domestik dengan transaksi total, perubahan struktur keterkiatan sektor perikanan tersebut ternyata belum dapat berubah meningkat tanpa menghilangkan ketergantungannya terhadap penggunaan input faktor yang berasal dari luar negeri dalam proses produksinya. Kedua temuan tersebut memberikan implikasi pentingnya mempertimbangkan kembali penerapan kebijakan dan strategi substitusi impor bagi pengembangan sektor perikanan Indonesia ke depan.
\end{abstract}

Kata Kunci: Keterkaitan, Perubahan Struktur, Sektor Perikanan

Abstract: $\quad$ Structural Change of Fisheries Sectors Linkage in The Indonesian Economy:An Analysis of the Multiplier Product Matrix (MPM) Using Soni's Technique. By: Tajerin

This study was aimed to analyzing the structural change of fisheries sectors linkage in the Indonesian Economy. Secondary data used in this research were obtained from Input Output Table of 1990, 1995 and 2000 for domestic transactions and total transactions based on Producer's Prices. Data analysis was done using I-O approach through Multiplier Product Matrix (MPM) with Soni's Technique. Results showed that during the analysis period (1990 - 2000), the fisheries sectors MPM of the domestic transactions economic landscapee with the other sectors are rising. However, the analysis also showed that there was a gap of average MPM value between domestic and total transactions by which tend to rise during the analized period. This indicates that the structural change fisheries sector is still heavily depended on import of inputs from abroad. The implication of those two findings was imperative to consider re-applying the old, abandoned import substitution policy and strategy for future fisheries sectors development.

Keywords: Structural Change, Linkages, Fisheries Sector, Indonesian Economy

${ }^{1}$ Peneliti pada Balai Besar Riset Sosial Ekonomi Kelautan dan Perikanan

JI. KS. Tubun, Petamburan VI Slipi Jakarta. E-mail: Jerin_Jmhr@yahoo.com 


\section{PENDAHULUAN}

Pembangunan perikanan selama tiga dasa warsa terakhir diposisikan sebagai sektor "pinggiran" (peripheral sector) dalam pembangunan ekonomi nasional (Kusumastanto, 2002). Dengan posisi semacam ini sektor perikanan bukan menjadi "arus utama" (main-stream) dalam kebijakan pembangunan ekonomi nasional. Kondisi ini menjadi ironis mengingat hampir $70 \%$ wilayah Indonesia merupakan wilayah pesisir dan lautan dengan potensi ekonomi yang sangat besar serta berada pada posisi geopolitis yang penting, yakni Lautan Pasifik dan Lautan Hindia sebagai kawasan paling dominan dalam percaturan dunia baik secara ekonomi dan politik di dunia.

Dalam perkembangannya kemudian, "wajah" sektor perikanan tersebut berubah dan mampu menunjukkan eksistensinya dalam perekonomian Indonesia, terutama setelah mendapatkan momentum baru dalam rangkaian pembangunan ekonomi nasional, yaitu dengan dibentuknya Departemen Kelautan dan Perikanan (DKP). Sejak berdirinya DKP, pertumbuhan pembangunan perikanan melaju dengan cukup tinggi. Hal ini antara lain dapat dilihat dari indikator pertumbuhan Product Domestic Bruto (PDB) sektor perikanan sejak tahun 2000 hingga 2004 yang terus meningkat dengan rata-rata kenaikan per tahun sebesar $17,07 \%$. Ratarata kenaikan $P D B$ perikanan ini secara relatif lebih tinggi dibanding dengan sektor pertanian lainnya bahkan dengan $P D B$ nasional (DKP, 2005a).

Dengan demikian, pada tataran kebijakan pembangunan ekonomi sudah selayaknya sektor perikanan menjadi sumber pertumbuhan baru perekonomian Indonesia, terutama melalui upaya mensinergikannya dengan sektor-sektor lain, dan dengan menggabungkan visi laut dan visi darat sehingga seluruh potensi ekonomi dapat dikembangkan secara terpadu. Pada kondisi seperti ini, kebijakan pembangunan ekonomi tidak lagi didasarkan pada "pemerasan pembangunan" (squeezed development) sektor lain (dalam hal ini sektor perikanan), namun didasarkan pada "pemanenan" yang paling efisien dan memberikan kontribusi maksimal bagi kemakmuran bangsa serta mampu menjawab tantangan persaingan global dan pembangunan berkelanjutan (sustainable development) (Dahuri, 1999a; 1999b).Oleh karena itu, untuk dapat mewujudkan hal tersebut, sektor perikanan haruslah memiliki keterkaitan ke depan dan ke belakang yang tinggi dengan sektor-sektor lain dalam perekonomian di Indonesia.

Namun demikian, peningkatan kontribusi ekonomi tersebut tentunya tidak terlepas dari pengaruh kebijakan-kebijakan ekonomi dari pemerintah. Kebijakan tersebut antara lain adalah kebijakan promosi ekspor, kebijakan kemudahan investasi, kebijakan substitusi impor dan kebijakan-kebijakan lainnya yang pernah digulirkan pemerintah dalam meningkatkan pertumbuhan ekonomi nasional. Interaksi antara berbagai kebijakan tersebut, tentunya akan berpengaruh terhadap kenaikan total keluaran dan peranan sektor perikanan dalam perekonomian nasional, yang pada gilirannya dapat mempengaruhi kondisi perubahan struktur keterkaitannya.

Dari fenomena di atas, hal penting yang perlu dicermati berkaitan dengan upaya untuk meningkatkan kontribusi ekonomi sektor perikanan secara luas dalam pembangunan Indonesia, diantaranya adalah mengenai perubahan struktur keterkiatan sektor perikanan. Pengetahuan mengenai hal ini sangat bermanfaat, karena dapat memberikan informasi yang dapat dijadikan acuan bagi formulasi kebijakan pembangunan perikanan sesuai dengan kecenderungan perubahan struktur keterkaitannya. Untuk itu, kajian ini dilakukan dengan tujuan mendapatkan gambaran mengenai perubahan struktur keterkaitan sektor perikanan dalam perekonomian Indonesia. 


\section{METODOLOGI}

\section{Landasan Teoritis}

Ada berbagai teori yang menjelaskan bagaimana keterkaitan antar sektor mempengaruhi perekonomian suatu negara. Bagi negara-negara di mana peranan sektor yang berbasiskan sumberdaya alam (natural resource base) seperti sektor perikanan, maka pemikiran mendinamiskan sektor tersebut melalui kekuatan dan keterkaitannya dengan sektor lain amat menarik untuk disimak.

Pemikiran Mellor dan Lee (1973) serta Mellor (1986; 1989) amat terkait dengan model rural-led strategy of growth. Disamping itu, Johnston and Kilby (1975) dan King and Byerlee (1978) menemukan bahwa keterkaitan industri dengan sektor yang berbasiskan sumberdaya alam amat kuat, apabila sektor industri mempunyai keterkaitan yang tinggi dengan sektor yang berbasis sumberdaya alam. Dengan menggunakan kasus sektor pertanian (termasuk di dalamnya adalah perikanan) sebagai salah satu sektor yang berbasiskan sumberdaya alam, Adelman (1984) menekankan pentingnya Agricultural Demand-Led Industrialization (ADLI). Dengan sejumlah analisis, ia berhasil membuktikan bahwa strategi ADLI lebih superior dibanding strategi export-led growth, khususnya apabila diterapkan di negara sedang berkembang di mana peranan sektor pertanian sebagai sektor yang berbasiskan sumberdaya alam masih substansial. Strategi ini menghendaki pergeseran strategi dari surplus extraction menjadi surplus creation, dan ditumbuhkannya keterkaitan permintaan antara sektor pertanian dengan sektor lain dalam perekonomian. Hal ini sejalan dengan pemikiran Sumodiningrat dan Kuncoro (1990) yang mencoba menuangkan pola simbiosis antara sektor pertanian (termasuk perikanan) dan industri melalui penerapan strategi pengembangan agroindustri dan agribisnis.

Pandangan Adelman mengenai pengembangan sektor pertanian (termasuk sektor perikanan) berbeda dengan Hirschman
(1958) dalam Jhingan (1991). Hirschman memandang sektor pertanian sebagai sektor yang pasif, sementara Adelman sebaliknya. Perbedaan pandangan itu terletak pada kriteria pemilihan sektor kunci (leading sector) dalam akselerasi pembangunan. Kriteria yang digunakan Hirschman dalam menentukan sektor kunci tersebut menurut pandangan Adelman terlalu sempit karena hanya mempertimbangkan keterkaitan produk, yang jelas akan menempatkan sektor pertanian pada sektor yang inferior. Padahal kenyataannya berdasarkan hasil penelitian Rangrajan (1982); Bell dan Hazell (1980); Adelman (1984); Haggblade et al. (1991); Haggblade dan Hazell (1989); Cavallo and Mundlak (1982), menunjukkan bahwa keterkaitan antara sektor pertanian (termasuk perikanan) dengan sektor industri tidak hanya keterkaitan produk, tetapi ada media keterkaitan lainnya yaitu: keterkaitan konsumsi, investasi dan tenaga kerja yang mampu menjelaskan secara lebih menyeluruh mengenai keterkaitan kedua sektor tersebut.

Di beberapa negara yang mengandalkan pertanian sebagai sektor andalannya, keterkaitan tersebut terbukti memberikan kemajuan yang berarti, seperti Costa Rica (Celes dan Lizano, 1995); Colombia (Berry, 1995); Kenya (Bigsten dan Collier, 1995); Argentina (Mundlak dan Donenech, 1995); dan India (Bhalla, 1995).

\section{Jenis dan Sumber Data}

Data yang digunakan dalam kajian ini adalah data sekunder dari buku Tabel InputOuput (I-O) Tahun 1990, 1995 dan 2000 yang disusun oleh Badan Pusat Statistik (1994, 1999, 2004). Dalam kajian ini digunakan dua jenis Tabel I-O, yaitu: (1) Tabel I-O transaksi domestik atas dasar harga produsen dimana setiap nilai transaksi hanya mencakup barang dan jasa domestik dan dinilai atas dasar harga produsen; dan (2) Tabel I-O transaksi total atas dasar harga produsen dimana unsur margin perdagangan dan biaya pengangkutan dipisahkan dari nilai input yang dibeli oleh 
setiap sektor dan diperlakukan sebagai input yang berasal dari sektor perdagangan dan pengangkutan.

Untuk dapat merekam peranan sektor perikanan, dalam penelitian ini digunakan Tabel I-O menurut klasifikasi 161 x 161 sektor untuk tahun 1995; 172 x 172 sektor untuk tahun 1995; dan $175 \times 175$ sektor untuk tahun 2000. Mengingat ukuran matrik masingmasing Tabel I-O tersebut tidak sama, pada tahap awal dilakukan konversi klasifikasi matriks Tabel I-O Tahun 1995 dan 2000 ke dalam klasifikasi matrik Tabel I-O Tahun 1990 yang memiliki klasifikasi terendah (161 x 161 sektor). Selanjutnya setelah semua Tabel I-O yang digunakan dalam kajian ini menjadi sama ukuran matriksnya, selanjutnya dilakukan pengklasifikasian kembali dengan cara mengagregasi beberapa sektor menjadi klasifikasi matriks $9 \times 9$ sektor, seperti tertera pada Tabel 1.

\section{Tabel 1. Pengklasifikasian Sektor-Sektor dari Tabel Input-Output yang digunakan dalam Kajian}

Table 1. Sectors Classification of I-O Table in The Analysis .

\begin{tabular}{|c|c|c|c|c|}
\hline \multirow[t]{2}{*}{$\begin{array}{l}\text { Sektor I } \\
\text { Sectors }\end{array}$} & \multirow[t]{2}{*}{$\begin{array}{l}\text { Deskripsi / } \\
\text { Description }\end{array}$} & \multicolumn{3}{|c|}{$\begin{array}{c}\text { Sektor-Sektor dalam Tabel Input-Output } \\
\text { ISectors within I-O Table }\end{array}$} \\
\hline & & 1990 & 1995 & 2000 \\
\hline 1. & $\begin{array}{l}\text { Pertanian non perikanan / Non Fisheries } \\
\text { Agriculture } \\
\text { Perikanan Primer / Primary Fisheries: }\end{array}$ & $1-28$ & $1-31$ & $1-30$ \\
\hline 2. & $\begin{array}{l}\text { Perikanan laut dan hasil perairan laut } \\
\text { lainnya / Marine Fisheries Sub Sector }\end{array}$ & 29 & $\left.32 ; 34 \operatorname{L}_{90}{ }^{*}\right)$ & $31 ; 33 \mathrm{~L}_{00^{* * *}}$ \\
\hline 3. & $\begin{array}{l}\text { and Its Produces } \\
\text { Perikanan darat dan hasil perairan darat } \\
\text { lainnya / Freshwater Fisheries Sub } \\
\text { Sector and Its Produces }\end{array}$ & 30 & 33; 34D ${ }_{90}^{* *)}$ & $32 ; 33 \mathrm{D}_{00}{ }^{* \star * *)}$ \\
\hline 4. & $\begin{array}{l}\text { Pertambangan dan penggalian / Mining } \\
\text { and Quarry } \\
\text { Perikanan Sekunder / Secondary }\end{array}$ & $32-34$ & $36-48$ & $35-48$ \\
\hline 5. & $\begin{array}{l}\text { Fisheries: } \\
\text { Industri pengeringan dan penggaraman }\end{array}$ & 31 & 53 & 53 \\
\hline & $\begin{array}{l}\text { ikan dan biota perairan lainnya / Sub } \\
\text { Sector Drying and Salting Processing } \\
\text { Industries }\end{array}$ & 48 & 54 & 54 \\
\hline 6. & $\begin{array}{l}\text { Industri pengolahan dan pengawetan } \\
\text { ikan dan biota perairan lainnya / Sub } \\
\text { Sector Processing and Preserving } \\
\text { Industries }\end{array}$ & & & \\
\hline 7. & $\begin{array}{l}\text { Industri pengolahan hasil pertanian non } \\
\text { perikanan / Agriculture Non Fisheries } \\
\text { Processing Industries }\end{array}$ & $\begin{array}{r}47-47 \\
49-83\end{array}$ & $\begin{array}{r}49-52 \\
55-91\end{array}$ & $\begin{array}{r}49-52 \\
55-93\end{array}$ \\
\hline 8. & $\begin{array}{l}\text { Industri pengolahan lainnya / Other } \\
\text { Processing Industries }\end{array}$ & $84-131$ & $92-139$ & $94-141$ \\
\hline 9. & $\begin{array}{l}\text { Jasa-jasa dan lainnya / Services and } \\
\text { Others }\end{array}$ & $132-161$ & $35 ; 140-172$ & $34 ; 142-175$ \\
\hline
\end{tabular}

Keterangan/ Remarks:

*) proporsi output sektor 34 (udang) untuk sektor 29 sebesar $54,1 \%$ yang berasal dari udang hasil tangkapan di laut pada tahun 1995 (BPS, 2004b)/ output proportion of 34 sectors (shrimp) for 29 sector is $54.1 \%$ from marine in 1995 (BPS, 2004b) 
**) proporsi output sektor 34 (udang) untuk sektor 30 sebesar $45,9 \%$ yang berasal dari udang hasil budidaya tambak dan tangkapan di perairan umum pada tahun 1995 (BPS, 2004b)/ output proportion of 34 sectosr (shrimp) for 30 sector is $54.9 \%$ from brackish water pond and inland water in 1995 (BPS, 2004b)

***) proporsi output sektor 34 (udang) untuk sektor 29 sebesar $54,5 \%$ yang berasal dari udang hasil tangkapan di laut pada tahun 2000 (BPS, 2004b)/ output proportion of 34 sectors (shrimp) for 29 sector is $54.5 \%$ from marine in 2000 (BPS, 2004b)

****) proporsi output sektor 34 (udang) untuk sektor 30 sebesar $54,5 \%$ yang berasal dari udang hasil budidaya tambak dan tangkapan di perairan umum pada tahun 2000 (BPS, 2004b)/output proportion of 34 sectors (shrimp) for 30 sector is $54.5 \%$ from brackish water pond and inland in 2000 (BPS, 2004b)

Tahap selanjutnya, agar dapat memperbandingkan antara perubahan riil di masing-masing tabel input output yang digunakan, dalam kajian ini dilakukan konversi (deflasi) besaran harga yang sebenarnya berlaku (the original current price) berdasarkan harga konstan (constant price) tahun tertentu. Secara empiris setidaknya terdapat dua metoda mendeflasi penggunaan Tabel I-O. Pertama, metoda pendeflasian berdasarkan harga konstan dengan tahun dasar yang ditentukan secara segmentasi (intertemporal comparison). Metoda ini dikenalkan oleh Commission of European Communitie, (1993) dalam Statistics Canada-Catalogue No. 15F0077GIE (2001). Kedua, metoda pendeflasian berdasarkan harga konstan satu tahun dasar tertentu yang diberlakukan untuk keseluruhan Tabel I-O yang digunakan dalam analisis.

Dalam kajian ini, pendeflasian terhadap tiga buah Tabel I-O, yaitu tahun 1990, 1995 dan 2000 yang digunakan dalam analisis dilakukan berdasarkan metoda "kedua", dengan menggunakan harga konstan tahun 1993 menurut "patokan" Produk Domestik Bruto (PDB) masing-masing sektor sebagai PDB defaltornya. Pengaplikasian angka indeks PDB deflator tersebut dilakukan dengan menggunakan teknik seperti yang digunakan oleh Kaneko (1984) dan merupakan salah satu teknik yang dianjurkan oleh BPS (2000). Metoda serupa telah digunakan untuk beberapa penelitian sejenis di beberapa negara lain pada tahun sebelumnya*.

\section{Metoda Analisis Data}

Salah satu model yang secara luas digunakan untuk menganalisis struktur perekonomian baik di tingkat nasional maupun regional termasuk untuk analisis yang bersifat spesifik sektoral adalah model I-O (Nazara, 1997). Dasar petimbangan utama digunakannya model I-O dalam kajian ini adalah bahwa dengan memanfaatkan tabel dasar dan tabel turunan, model I-O secara kuantitatif dapat memberikan gambaran menyeluruh mengenai struktur perekonomian, dan meskipun model I-O bersifat statis, namun dengan membandingkan dua tabel atau lebih yang meliputi periode waktu yang berlainan maka arah perubahan struktur masing-masing sektor dapat diketahui (Liu and Saal, 2000).

Analisis perubahan struktur melalui penggunaan model I-O menjangkau beberapa aspek, diantaranya adalah perubahan struktur dari aspek permintaan dan komponennya, perubahan struktur dari aspek penawaran dan komponennya, dan perubahan struktur yang dilihat berdasarkan derajat keterkaitannya baik ke belakang maupun ke depan. Dalam kajian ini, perubahan struktur keterkaitan

\footnotetext{
*Metoda ini telah digunakan pula oleh Akita (1991, 1992 dan 1994), Chenery (1980 dan 1986), Feldman et al. (1987), Holland and Cooke (1992), James and Fujita (1989), Kubo et al. (1986), Lee dan Schluter (1993), Martin and Holland (1992), Soni's et al. (1996), dan Urata (1987).
} 
sektor perikanan terhadap sektor-sektor lainnya dalam perekonomian Indonesia dianalisis berdasarkan derajat keterkaitannya ke depan maupun ke belakang.

Dalam pelaksanaannya, analisis perubahan struktur keterkaitan sektor perikanan tersebut dianalisis dengan meggunakan Soni's Techniques, yaitu dengan cara menghitung nilai "Multiplier Product Matrix" (MPM) dari Tabel I-O (Guo and Planting, 2000). Hasil perhitungan MPM tersebut disajikan dalam bentuk grafik yang disebut sebagai "economic landscape", sehingga dapat mempermudah kita untuk melihat perubahan struktur keterkaitan antar sektor dari satu periode ke periode yang lain. Dengan kata lain, secara visual melalui teknik tersebut dapat dideskripsikan struktur keterkaitan antar sektor pada suatu periode dan perubahannya pada periode yang lain. Adapun perhitungan nilai MPM tersebut diperoleh dengan cara sebagai berikut. Misalnya $\mathrm{V}$ adalah jumlah total dari nilai pengganda semua sektor yang diperoleh dari matrik invers Leontief:

$$
V=\sum_{i=1}^{n} \sum_{j=1}^{n} b_{i j}
$$

Selanjutnya, nilai input-output MPM diperoleh dengan formulasi:

$$
M P M=\frac{1}{V}\left\|b_{i \bullet \bullet} b_{\bullet j}\right\|=\frac{1}{V}\left(\begin{array}{c}
b_{i \bullet} \\
b_{2 \bullet} \\
\vdots \\
b_{n \bullet}
\end{array}\right)\left(\begin{array}{lll}
b_{\bullet 1} & b_{\bullet 2} \cdots & \left.b_{\bullet n}\right) \\
\ldots & \ldots
\end{array}\right.
$$

dimana:

$\mathrm{V}=$ jumlah semua komponen di dalam matriks invers Leontief/The sum of all componets in invers Leontief Matrix

$b_{i \bullet}=$ jumlah semua kolom dalam baris ke$i$ dari matriks invers Leontief atau seperti yang digunakan dalam mengukur besaran keterkaitan ke depan /The sum of all column on the row of I from invers Leontief matrix or as to be used to measure the forward linkage

$b_{\bullet j}=$ jumlah semua kolom dalam kolom ke-j dari matriks invers Leontief atau seperti yang digunakan dalam mengukur besaran keterkaitan ke depan/The sum of all column on the row of $j$ from invers Leontief matrix or to be used to measure the forward linkage

Penjumlahan secara vertikal kolom ke-j $\left(m_{j}\right)$ pada MPM nilainya sama dengan penjumlahan secara vertikal kolom ke-j $\left(b_{j}\right)$ pada matrik kebalikan. Demikian pula dengan penjumlahan secara horisontal baris ke-i $\left(m_{i}\right)$ pada MPM sama dengan penjumlahan secara horizontal baris ke-i $\left(b_{i}\right)$ pada matrik kebalikan. Persamaan MPM tersebut dapat dituliskan sebagai berikut:

$$
M P M=\left(1 / V^{*} F L * B L\right)
$$
dimana:
$\mathrm{V}=$ jumlah semua komponen di dalam matriks Leontief/The sum of all component in Leotief matrix
$\mathrm{FL}=$ derajat kepekaan/ keterkaitan ke depan/Degree of sensitivity/forward linkages
$\mathrm{BL}=$ daya penyebaran/ keterkaitan ke b e I a kang Spreading power/backward linkages

Hasil perhitungan MPM dalam kajian ini disajikan dalam bentuk grafik tiga dimensi untuk memvisualisasikan struktur perekonomian (economic landscape) yang disusun secara hirarkis. Hirarki secara vertikal pada MPM susunannya sama dengan hirarki berdasarkan daya penyebaran (backward linkages), sedangkan hirarki secara horisontal susunannya sama dengan hirarki berdasarkan derajat kepekaan (forward linkages). MPM yang telah disusun secara hirarkis tersebut jika dibuat grafik akan membentuk suatu landscape dimana kolom tertinggi terletak 
pada kiri atas dan melandai ke arah kanan bawah. Ketinggian landscape menunjukkan besarnya keterkaitan sektor dengan perekonomian. Semakin tinggi landscape menunjukkan bahwa sektor tersebut lebih kuat keterkaitannya dengan perekonomian. Dengan kata lain tingkat ketinggian dan bentuk landscape MPM tergantung pada keterkaitan antar sektor dalam perekonomian. Selanjutnya agar "economic landscape" yang dihasilkan dapat diperbandingkan, maka hirarki keterkaitan ke belakang dan ke depan antar sektor ekonomi pada tahun 1990 digunakan sebagai tahun referensi untuk tahun 1995 dan 2000. Dengan kata lain, "economic landscape" tahun 1995 dan 2000 disusun berdasarkan hirarki tahun 1990.

Dalam kajian ini, untuk menghitung besaran angka MPM yang digunakan dalam analisis dilakukan dengan menggunakan Software PylO (Nazara et al., 2004).

\section{HASIL DAN PEMBAHASAN}

Visualisasi struktur keterkaitan antar sektor dalam perekonomian dapat ditunjukkan melalui "economic landscape" dari hasil perhitungan Multiplier Product Matrix (MPM) dapat dijelaskan pada uraian berikut.

\section{A. Economic Landscape dari MPM Transaksi Domestik}

Berdasarkan "economic landscape" Multiplier Product Matrix (MPM)-nya (seperti terlihat pada Gambar 1, 2 dan 3), dapat diketahui bahwa keterkaitan antar sektor di Indonesia selama periode analisis (1990-

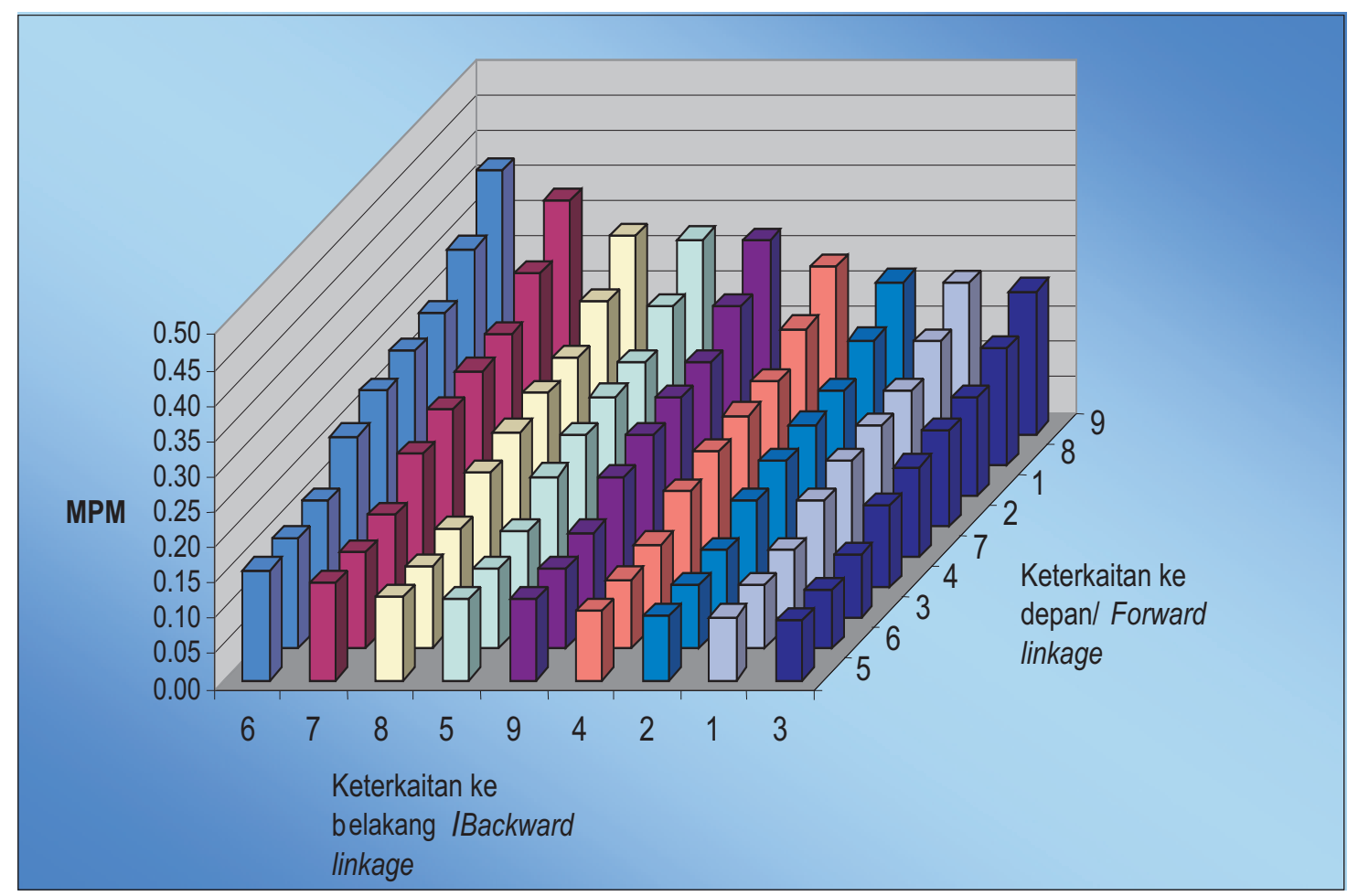

Gambar1. Economic Landscape Transaksi Domestik dari Sektor-Sektor dalam Perekonomian Indonesia Tahun 1990

Figure 1. Economic Landscape for Domestic Transaction of Indonesian Economy Sectors in 1990 


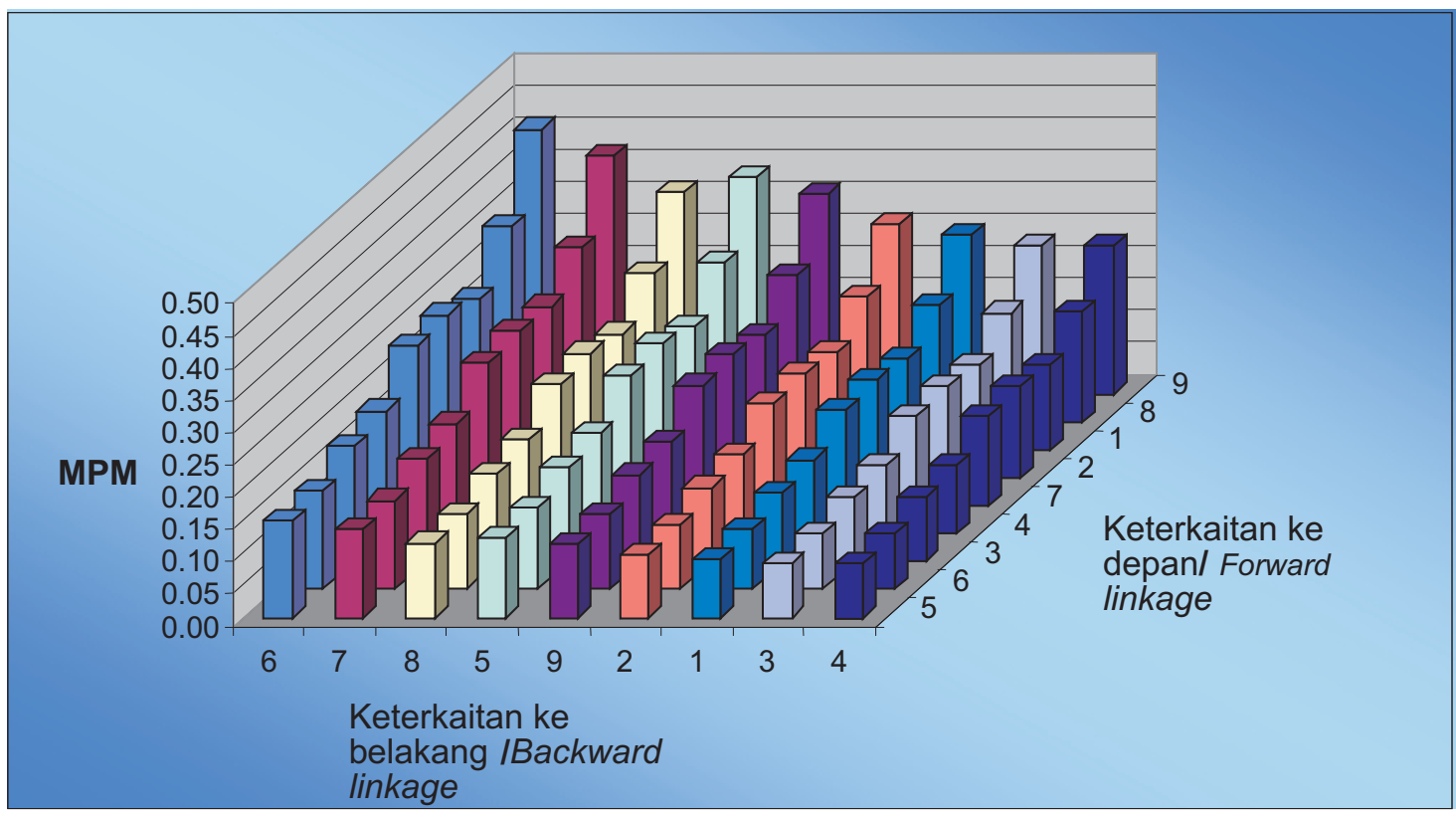

Gambar 2. Economic Landscape Transaksi Domestik dari Sektor-Sektor dalam Perekonomian Indonesia Tahun 1995 menurut Hirarki Tahun 1990

Figure 2. Economic Landscape for Domestic Transaction of Indonesian Economy Sectors in 1995, according to1990 Hierarchy

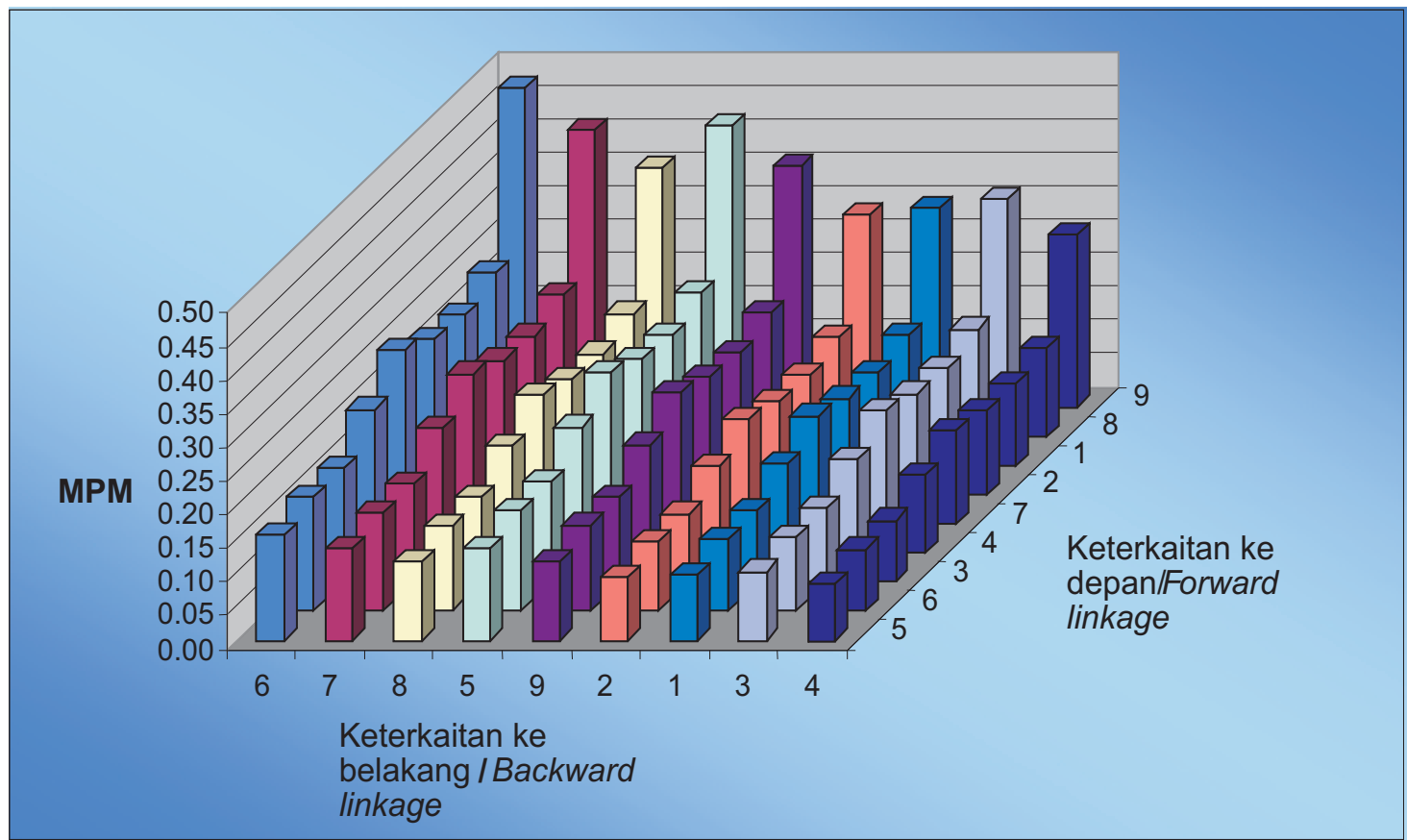

Gambar 3. Economic Landscape Transaksi Domestik dari Sektor-Sektor dalam Perekonomian Indonesia Tahun 2000 menurut Hirarki Tahun 1990

Figure 3. Economic Landscape. Domestic Transaction from Indonesian Economy Sectors in 2000 according to 1990 Hierarchy 
2000) semakin meningkat. Hal ini dapat terlihat dari peningkatan rata-rata ketinggian kolom economic landscape dari MPM untuk keseluruhan sektor dalam perekonomian Indonesia yang meningkat dari sebesar 0,167594 pada tahun 1990 menjadi sebesar 0,173306 pada tahun 1995, kemudian meningkat lagi menjadi sebesar 0,176238; atau terjadi perubahan peningkatan rata-rata sebesar $3,41 \%$ pada periode $1990-1995$, dan sebesar $1,69 \%$ pada periode $1995-2000$ (Tabel 2). Lebih lanjut dari ketiga "economic landscape" pada Gambar 1, 2 dan 3 terlihat bahwa permukaan (ketinggian kolom) landscape-nya mengalami perubahan. Secara relatif perubahan tersebut dapat dilihat pula pada Tabel 2, khususnya untuk perubahan khususnya untuk perubahan

Tabel2. Rata-rata dan Variasi Ketinggian Kolom "Economic Landscape" Transaksi Domestik Sektor-Sektor dalam Perekonomian Indonesia, Tahun 1990-2000

Table 2. Average and Height Variance of Economic-Landscape Column for Domestic Transactions of Indonesian Economy During 1990-2000

\begin{tabular}{|c|c|c|c|c|c|}
\hline \multirow{2}{*}{$\begin{array}{c}\text { Sektor Menurut } \\
\text { Peringkat MPM / } \\
\text { Sectors' Position in } \\
\text { Terms of MPM }\end{array}$} & \multicolumn{3}{|c|}{ Tahun/Year } & \multicolumn{2}{|c|}{$\begin{array}{c}\text { Perubahan (\%)/Changes } \\
(\%)\end{array}$} \\
\hline & 1990 & 1995 & 2000 & 1990-1995 & $1995-2000$ \\
\hline $\begin{array}{l}\text { A. Rata-rata MPM / } \\
\text { Average of MPM }\end{array}$ & & & & & \\
\hline - Sektor/ Sector-6 & 0,234652 & 0,236110 & 0,238293 & 0,62 & 0,92 \\
\hline - Sektor/ Sector -7 & 0,207525 & 0,213361 & 0,206303 & 2,81 & $-3,31$ \\
\hline - Sektor/ Sector-8 & 0,176741 & 0,180202 & 0,177466 & 1,96 & $-1,52$ \\
\hline - Sektor/ Sector-5 & 0,172708 & 0,192914 & 0,208931 & 11,70 & 8,30 \\
\hline - Sektor/ Sector-9 & 0,171577 & 0,178107 & 0,179462 & 3,81 & 0,76 \\
\hline - Sektor/ Sector-2 & 0,148322 & 0,151898 & 0,143554 & 2,41 & $-5,49$ \\
\hline - Sektor/ Sector-1 & 0,135219 & 0,141983 & 0,148377 & 5,00 & 4,50 \\
\hline - Sektor/ Sector-3 & 0,134549 & 0,132507 & 0,155046 & $-1,52$ & 17,01 \\
\hline - Sektor/ Sector-4 & 0,127054 & 0,132677 & 0,128716 & 4,43 & $-2,99$ \\
\hline $\begin{array}{l}\text { Rataan Keseluruhan/ } \\
\text { Total Average }\end{array}$ & 0,167594 & 0,173306 & 0,176238 & 3,41 & 1,69 \\
\hline $\begin{array}{l}\text { B. Variasi MPM I } \\
\text { Variance of MPM }\end{array}$ & & & & & \\
\hline - Sektor/ Sector -6 & 0,004697 & 0,006056 & 0,008219 & 28,95 & 35,71 \\
\hline - Sektor/ Sector -7 & 0,003673 & 0,004896 & 0,006160 & 33,28 & 25,82 \\
\hline - Sektor/ Sector -8 & 0,002664 & 0,003528 & 0,004558 & 32,29 & 29,22 \\
\hline - Sektor/ Sector -5 & 0,002544 & 0,004043 & 0,006318 & 58,91 & 56,28 \\
\hline - Sektor/ Sector -9 & 0,002511 & 0,003446 & 0,004662 & 37,24 & 35,27 \\
\hline - Sektor/ Sector -2 & 0,001876 & 0,002507 & 0,002983 & 33,58 & 19,00 \\
\hline - Sektor/ Sector -1 & 0,001560 & 0,002190 & 0,003187 & 40,42 & 45,50 \\
\hline - Sektor/ Sector -3 & 0,001544 & 0,001907 & 0,003479 & 23,52 & 82,41 \\
\hline - Sektor/ Sector -4 & 0,001377 & 0,001912 & 0,002398 & 38,89 & 25,40 \\
\hline $\begin{array}{l}\text { Variasi Keseluruhan/ } \\
\text { Total Variance }\end{array}$ & 0,002494 & 0,003387 & 0,004663 & 35,81 & 37,65 \\
\hline
\end{tabular}

Sumber: Diolah Berdasarkan Hasil Perhitungan Lampiran 1/ Source: Extracted from calculation of Appendix 1.

Keterangan/remarks:

- Sektor-1/Sector-1 = sektor pertanian non perikanan/ Non-fisheries agriculture sector 
- Sektor-2/Sector-2 = sektor perikanan laut dan hasil perairan laut lainnya/ Marine fisheries and other marine fisheries product sector

- Sektor-3/Sector-3 = sektor perikanan darat dan hasil perairan darat lainnya/ Inland fisheries and otherInland fisheries product sector

- Sektor-4/Sector-4 = sektor pertambangan dan galian/ Quarrying and mining sector

- Sektor-5/Sector-5 = sektor industri pengeringan ikan dan biota perairan lainnya/ Dried and salted processing industry

- Sektor-6/Sector-6 = sektor industri pengolahan dan pengawetan ikan dan biota perairan lainnya/ Processing and preserving industry

- Sektor-7/Sector-7 = sektor industri pengolahan hasil pertanian non perikanan/ Nonfisheries agriculture

- Sektor-8/Sector-8 = sektor industri pengolahan lainnya/ Other processing industry

- Sektor-9/ Sector-9 = sektor jasa-jasa dan lainnya/ Other services

masing-masing sektor dalam perekonomian Indonesia selama periode analisis. Perubahan permukaan (ketinggian kolom) "economic landscape" dari MPM tersebut mengindikasikan adanya perubahan yang terjadi pada keterkaitan masing-masing sektor terhadap perekonomian secara keseluruhan.

Sektor-sektor yang keterkaitannya mengalami perubahan cenderung yang meningkat selama periode analisis (19902000) adalah industri pengolahan dan pengawetan ikan, industri pengeringan dan penggaraman ikan, jasa-jasa dan lainnya, pertanian non perikanan. Sedangkan keterkaitan industri pengolahan hasil perikanan non perikanan, industri pengolahan lainnya, perikanan laut, pertambangan dan galian mengalami perubahan yang fluktuatif selama periode periode analisis, yaitu meningkat pada periode 1990-1995 kemudian menurun pada periode 1995-2000. Sementara itu untuk perikanan darat juga mengalami perubahan yang fluktuatif selama periode analisis, namun dengan pola perubahan yang berbeda, yaitu diawali dengan perubahan yang menurun pada periode 1990-1995, kemudian meningkat pada periode 1995-2000. Dengan demikian, dari temuan tersebut diketahui bahwa antara sektor-sektor terkait dengan perikanan primer dan perikanan sekunder memiliki kecenderungan perubahan yang berbeda dalam struktur keterkaitannya dengan sektor- sektor lainnya dalam perekonomian selama periode analisis.

Untuk perikanan primer yang terdiri dari perikanan laut dan perikanan darat menunjukkan perubahan struktur keterkaitan yang cenderung fluktuatif. Pada periode tahun 1990-1995 rata-rata MPM perikanan laut mengalami perubahan meningkat sebesar 2,41\% (dari rata-rata MPM sebesar 0,148322 pada tahun 1990 meningkat menjadi sebesar 0,151898 pada tahun 1995), dan rata-rata MPM perikanan darat berubah menurun sebesar $-1,52 \%$ (dari rata-rata MPM sebesar 0,134549 pada tahun 1990 menurun menjadi sebesar 0,132507 pada tahun 1995). Kemudian pada periode tahun 1995-2000 rata-rata MPM perikanan laut mengalami penurunan sebesar $-5,49 \%$ (dari rata-rata MPM sebesar 0,151898 pada tahun 1995 menurun menjadi sebesar 0,143554 pada tahun 2000), dan perikanan darat meningkat sebesar $17,01 \%$ (dari rata-rata MPM sebesar 0,132507 pada tahun 1995 meningkat menjadi sebesar 0,155046 pada tahun 2000).

Sementara itu, untuk perikanan sekunder yang terdiri dari industri pengeringan dan penggaraman ikan dan industri pengolahan dan pengawetan ikan menunjukkan perubahan struktur keterkaitan yang cenderung meningkat. Pada periode 19901995 rata-rata MPM kedua sektor tersebut mengalami perubahan yang meningkat masing-masing sebesar $11,70 \%$ dan $0,62 \%$ 
(dari rata-rata MPM sebesar 0,172708 dan 0,234652 pada tahun 1990 kemudian meningkat menjadi sebesar 0,192914 dan 0,236110 pada tahun 1995). Selanjutnya pada periode 1995-2000 rata-rata MPM kedua sektor tersebut berubah meningkat kembali masing-masing sebesar $8,30 \%$ dan $0,92 \%$ (dari rata-rata MPM sebesar 0,192914 dan 0236110 pada tahun 1995 meningkat menjadi sebesar 0,208931 dan 0,238293 pada tahun 2000).

Dari visualisasi "economic landscape" MPM pada Gambar 1, 2 dan 3 dapat diketahui pula bahwa ketinggian kolom pada "keterkaitan silang" antara sektor-sektor ekonomi dengan sektor jasa-jasa dan lainnya (untuk tahun 1990, 1995 dan 2000) dan dengan sektor industri pengolahan lainnya (untuk tahun 1990 dan 1995) tergolong sangat menonjol. Hal ini mengindikasikan bahwa seluruh sektor ekonomi dari transaksi domestik selama periode analisis (1990-2000) mempunyai ketergantungan yang sangat tinggi dengan sektor jasa-jasa dan lainnya. Hal yang sama berlaku pula untuk sektorsektor terkait perikanan dan industri pengolahan hasil perikanan. Sektor-sektor yang mempunyai ketergantungan tertinggi dengan sektor jasa-jasa dan lainnya, dan industri pengolahan lainnya untuk periode yang sama (1990-2000) adalah industri pengolahan dan pengawetan ikan, kemudian disusul oleh industri pengeringan dan penggaraman ikan, perikanan laut dan perikanan darat.

Selanjutnya dari Gambar 1, 2 dan 3 tersebut juga dapat dilihat bahwa permukaan economic landscape dari MPM cenderung semakin tidak rata. Kecenderungan tersebut diperjelas dengan hasil perhitungan "population variance" seperti tertera pada pada Tabel 2 yang memperlihatkan adanya kecendrungan peningkatan variasi ketinggian kolom economic landscape MPM selama periode analisis. Variasi economic landscape MPM tersebut meningkat dari sebesar 0,002494 pada tahun 1990 menjadi sebesar
0,003387 pada tahun 1995, dan kemudian meningkat kembali menjadi sebesar 0,0004663 pada tahun 2000. Atau terjadi peningkatan ketinggian kolom economic landscape MPM sebesar $35,81 \%$ pada periode tahun 1990-1995, dan kemudian meningkat kembali dengan perubahan sebesar $37,65 \%$ pada periode 1995-2000. Dengan semakin meningkatnya variasi ketinggian kolom economic landscape MPM tersebut mengindikasikan semakin tingginya perbedaan keterkaitan masing-masing sektor terhadap perekonomian secara keseluruhan.

Lebih lanjut bila perbedaan ketinggian kolom economic landscape MPM transaksi domestik tersebut dilihat untuk masing-masing sektor, dapat dibedakan menjadi dua kecenderungan peningkatan ketinggian kolom economic landscape MPM. Pertama, sektorsektor yang memiliki kecenderungan variasi ketinggian kolom economic landscape MPM selama periode analisis yang meningkat dengan peningkatan yang bertambah, yaitu industri pengolahan dan pengawetan ikan, industri pengeringan dan penggaraman ikan, pertanian non perikanan, dan perikanan darat. Kedua, sektor-sektor yang memiliki kecenderungan variasi ketinggian kolom economic landscape MPM selama periode analisis meningkat namun dengan peningkatan yang berkurang, yaitu industri pengolahan hasil pertanian non perikanan, industri pengolahan lainnya, jasa-jasa dan lainnya, perikanan laut, dan pertambangan dan galian.

Khusus untuk sektor-sektor yang terkait dengan perikanan (baik perikanan primer maupun perikanan sekunder), ternyata dari perbedaan kecenderungan variasi ketinggian kolom economic landscape MPM tersebut (Gambar 1, 2 dan 3 serta Tabel 2) industri pengolahan dan pengawetan ikan dan perikanan darat memiliki kecenderungan yang meningkat dengan peningkatan yang bertambah. Pada periode tahun 1990-1995 masing-masing sektor tersebut meningkat sebesar $28,95 \%$ dan $23,52 \%$ kemudian pada 
periode 1995-2000 kembali meningkat dengan peningkat yang lebih besar masingmasing sebesar $35,71 \%$ dan $82,41 \%$. Sebaliknya untuk industri pengeringan dan penggaraman ikan dan perikanan laut memiliki kecenderungan variasi ketinggian kolom economic landscape MPM yang cenderung meningkat namun dengan peningkatan berkurang. Pada periode tahun 1990-1995 kedua sektor ini memiliki kecenderungan meningkat masing-masing sebesar $58,91 \%$ dan $33,58 \%$, dan pada periode 1995-2000 kembali meningkat namun dengan peningkatan yang lebih rendah masing-masing sebesar $56,28 \%$ dan $19,00 \%$.

\section{B. Economic Landscape dari MPM Transaksi Total dan Perbandingnya dengan Transaksi Domestik}

Jika dibandingkan dengan transaksi total, rata-rata ketinggian kolom economic Landscape dari MPM transaksi domestik ternyata lebih rendah. Hal ini dapat dilihat dari perbandingan antara Gambar 1, 2 dan 3 dengan Gambar 4, 5 dan 6. Perbedaan ratarata ketinggian kolom transaski domestik dengan transaksi total semakin besar selama periode analisis (1990-2000) mengindikasikan semakin meningkatnya penggunaan barang dan jasa impor dalam proses produksi.

Dari Tabel 4 terlihat bahwa secara ratarata perbedaan tersebut meningkat sebesar dari 0,017876 pada tahun 1990 menjadi sebesar 0,019043 pada tahun 1995, kemudian meningkat lagi menjadi sebesar 0,035224 pada tahun 2000. Atau terdapat perubahan yang meningkat dari sebesar $0,30 \%$ selama periode 1990-1995 menjadi sebesar 8,25\% pada periode 1995-2000. Jika pada tahun 1990 perbedaan rata-rata ketinggian kolom economic landscape dari MPM untuk keseluruhan sektor pada transaksi total adalah sebesar 0,185470, maka pada tahun 1995 dan 2000 masing-masing menjadi 0,192349 dan 0,211462 . Atau meningkat sebesar $3,71 \%$ pada periode 1990-1995 dan kembali

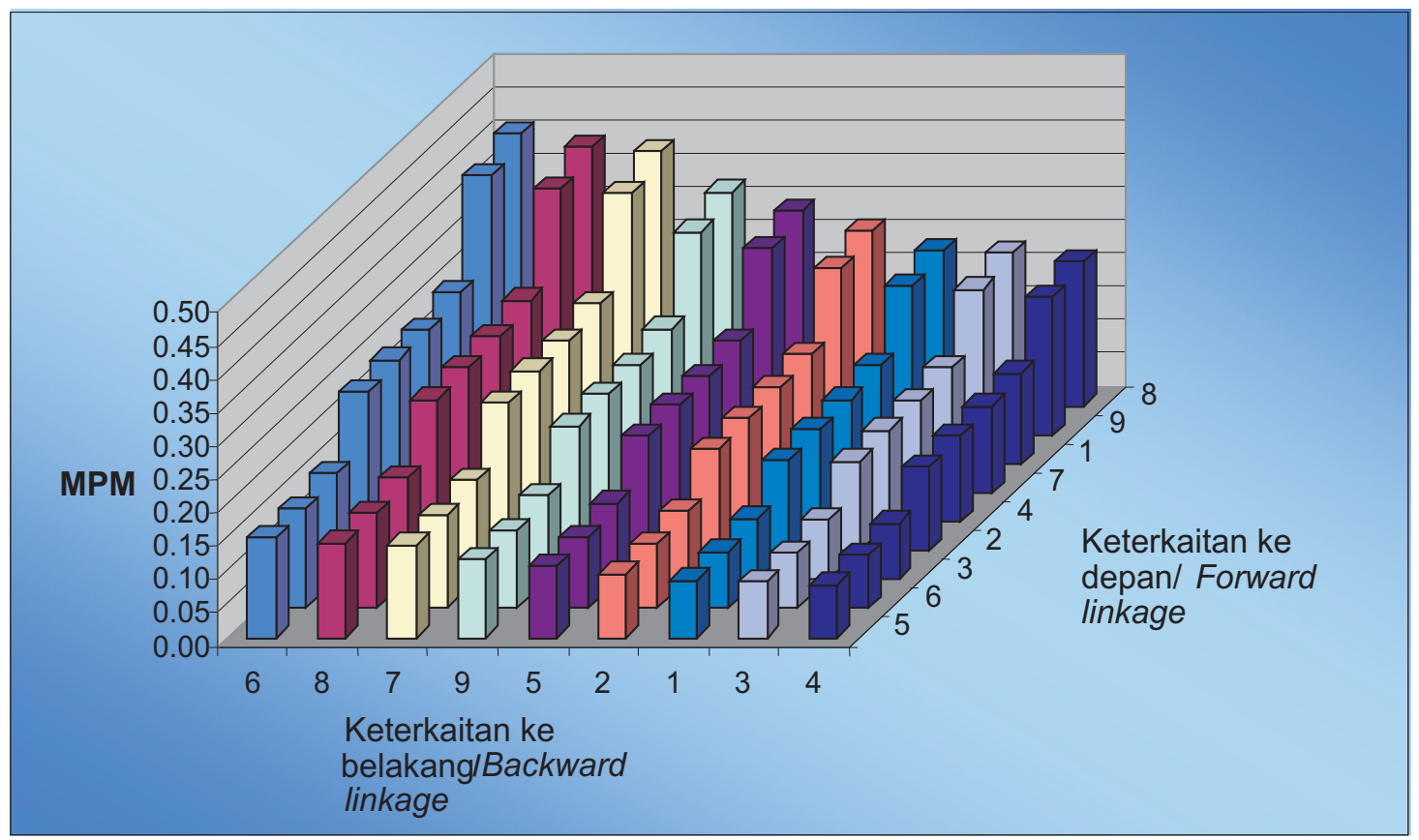

Gambar 4. Economic Landscape Transaksi Total dari Sektor-Sektor dalam Perekonomian Indonesia Tahun 1990

Figure 4. Economic Landscape for Total Transactions of Indonesian Economy Sectors in 1990 


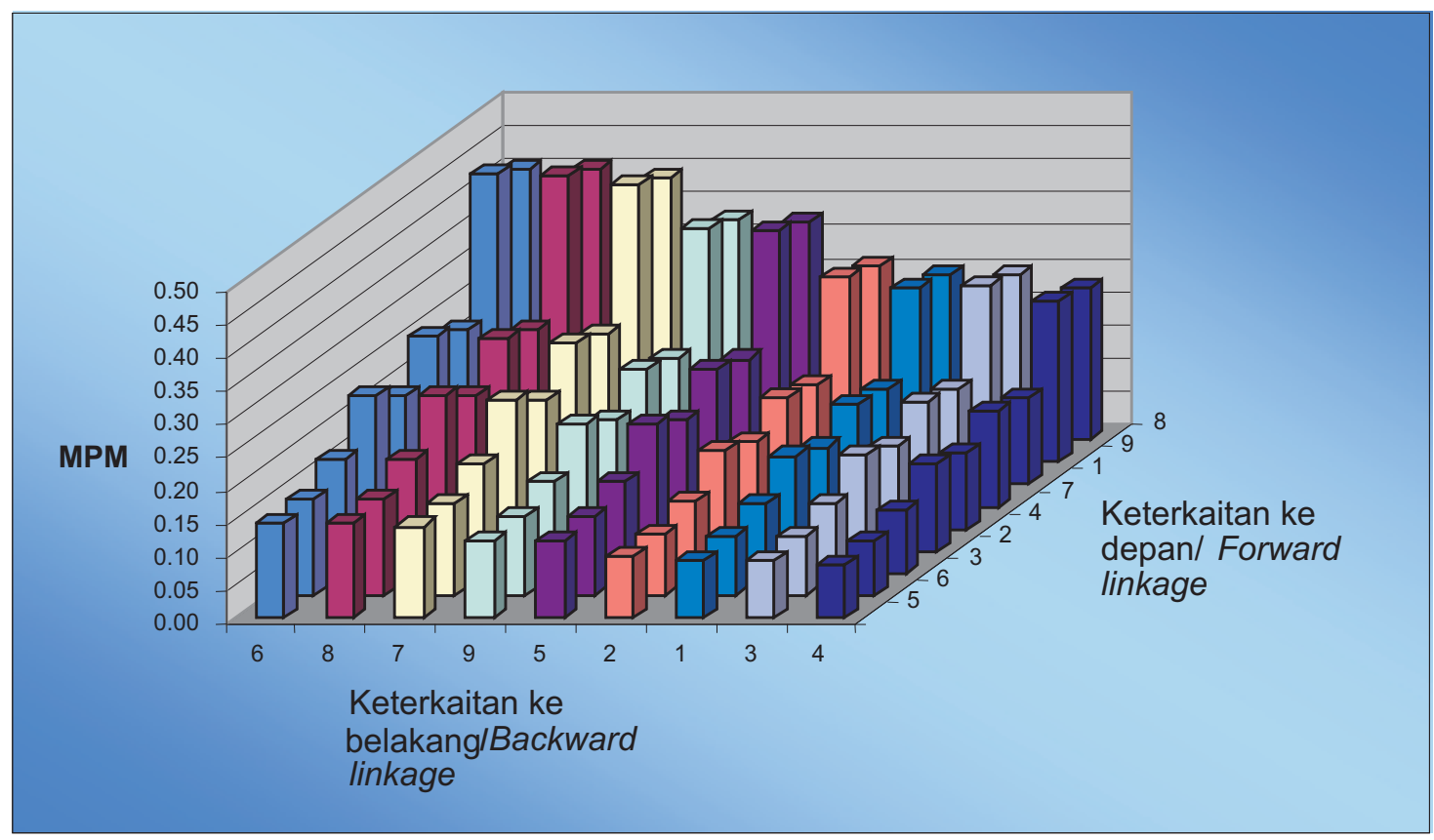

Gambar 5. Economic Landscape Transaksi Total dari Sektor-Sektor dalam Perekonomian Indonesia Tahun 1995 menurut Hirarki Tahun 1990

Figure 5. Economic Landscape for Total Transactions of Indonesian Economy Sectors in 1995 according to 1990 Hierarchy

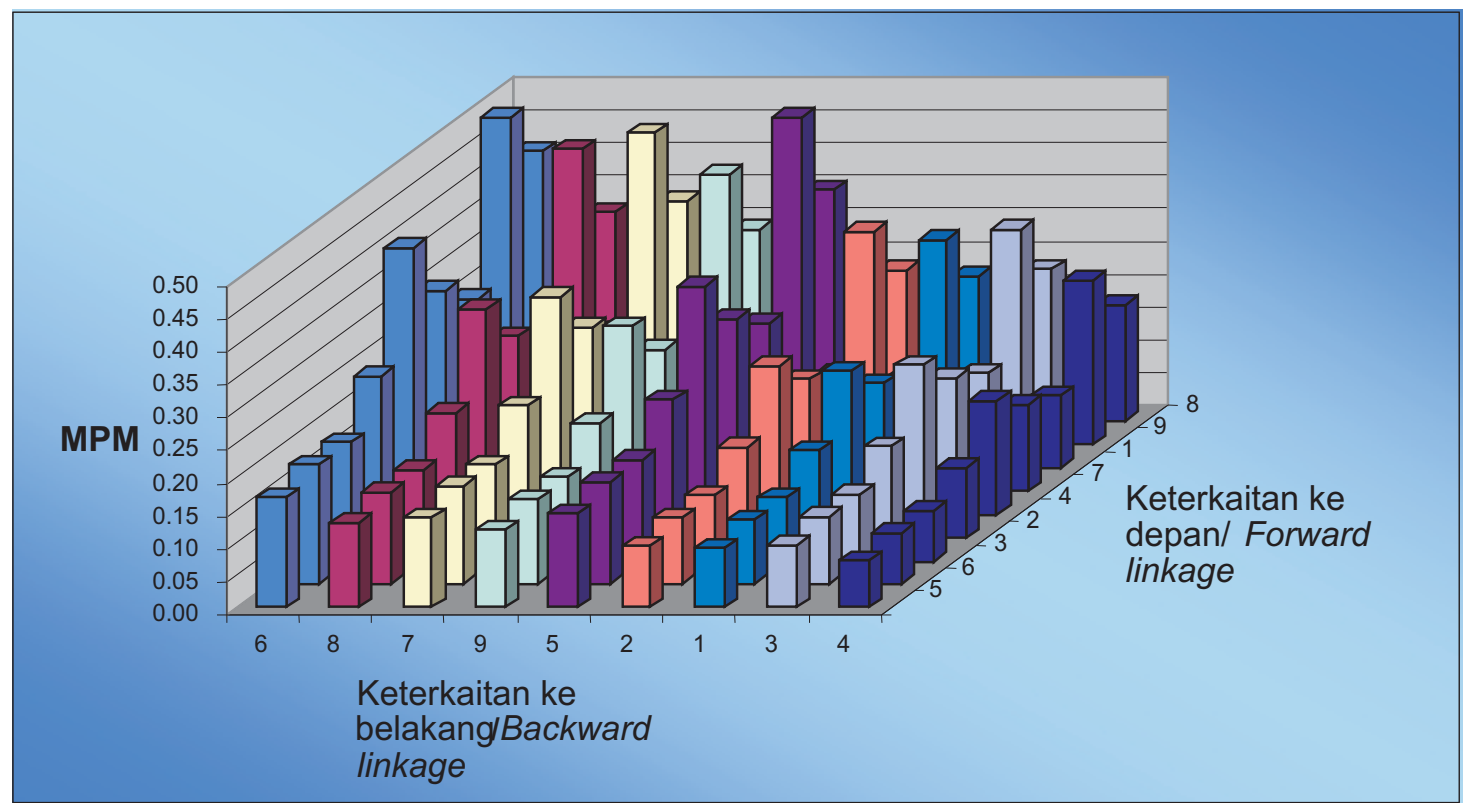

Gambar6. Economic Landscape Transaksi Total dari Sektor-Sektor dalam Perekonomian Indonesia Tahun 2000 menurut Hirarki Tahun 1990

Figure 6. Economic Landscape for Total Transactions of Indonesian Economy Sectors in 2000 according to 1990 Hierarchy 
meningkat sebesar $9,94 \%$ pada periode 1995 2000. Sedangkan jika dibandingkan antara economic landscape MPM dari transaski total dan transaski domestik terdapat perbedaan masing-masing pada tahun 1990, 1995 dan
2000 masing-masing sebesar 0,002248, 0,002954 dan 0,004088 . Atau pada periode 1990-1995 terdapat perbedaan sebesar $0,30 \%$ dan pada periode $1995-2000$ sebesar $8,25 \%$ (Tabel 3).

Tabel 3. Rata-rata dan Variasi Ketinggian Kolom "Economic Landscape"Transaksi Total Sektor-Sektor dalam Perekonomian Indonesia, Tahun 1990-2000

Table 3. Average and Height Variance of Economic-Landscape Columns for Total Transaction of Indonesian Economy during 1990-2000

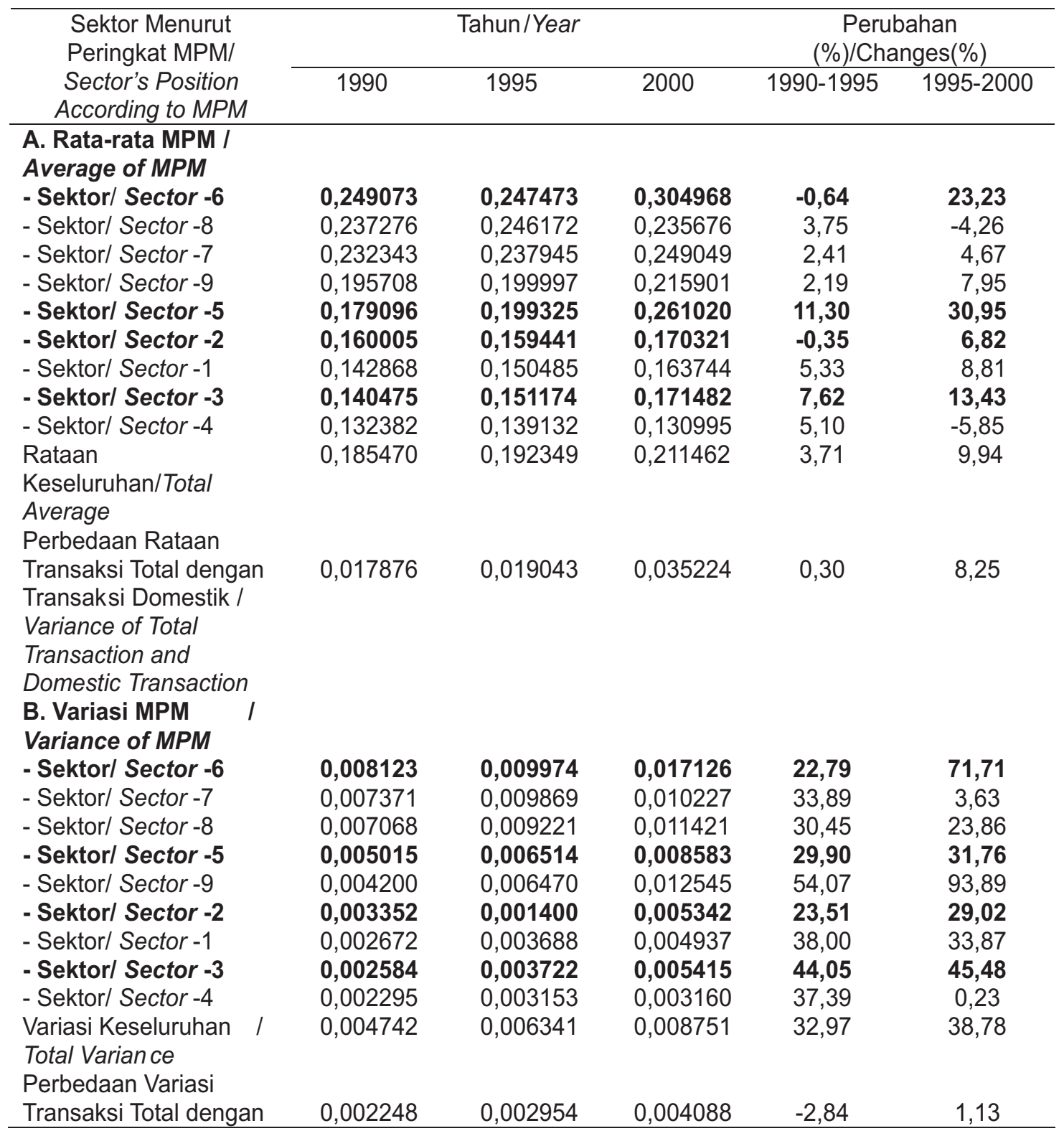

Sumber: Diolah Berdasarkan Hasil Perhitungan Lampiran 2/ Source: Extracted from calculation of Appendix 2 
Keterangan/ Remarks :

- Sektor-1/ Sector-1

- Sektor-2/ Sector-2

= sektor pertanian non perikanan/ Non-Fisheries Agriculture Sector

= sektor perikanan laut dan hasil perairan laut lainnya/ Marine Fisheries and Other Marine Fisheries Product Sector

- Sektor-3/ Sector-3

= sektor perikanan darat dan hasil perairan darat lainnya/ Inland Fisheries and other Inland Fisheries Product Sector

- Sektor-4/Sector-4

- Sektor-5/ Sector-5

- Sektor-6/ Sector-6

= sektor pertambangan dan galian/ Quarrying and Mining Sector

= sektor industri pengeringan ikan dan biota perairan lainnya/ Dried and Salted Processing Industry

= sektor industri pengolahan dan pengawetan ikan dan biota perairan lainnya Processing and Preserving Industry I

- Sektor-7/ Sector-7

$=$ sektor industri pengolahan hasil pertanian non perikanan/ Non-Fisheries Agriculture

- Sektor-8/ Sector-8 = sektor industri pengolahan lainnya/ Other Processing Industry

- Sektor-9/ Sector-9= sektor jasa-jasa dan lainnya/ Other Services

Indikasi bahwa impor barang dan jasa mengakibatkan semakin besarnya variasi keterkaitan antar sektor pada transaksi total dapat dilihat dari "population variance" ketinggian kolom transaksi total yang lebih besar dari transaksi domestik. Pada Tabel 3 terlihat bahwa perbedaan variasi MPM tersebut pada tahun 1990, 1995 dan 2000 masing-masing sebesar 0,002248, 0,002954 dan 0,004088 . Untuk transaksi total sendiri, selama periode analisis ketinggian kolom economic landscape MPM tersebut pada transaksi total cenderung semakin besar, yaitu meningkat dari sebesar 0,004742 pada tahun 1990 menjadi sebesar 0,006341 pada tahun 1995, dan kembali meningkat menjadi sebesar 0,008751 pada tahun 2000. Atau meningkat sebesar 32,97\% pada periode 1990-1995 dan kembali meningkat sebesar $38,78 \%$ pada periode 1995-2000 (Tabel 4). Semakin besarnya perbedaan keterkaitan antar sektor tersebut mengindikasikan semakin besarnya saling ketergantungan dari seluruh sektor dalam perekonomian. Kecenderungan ini dapat dilihat dari tingginya kolom pada keterkaitan silang seluruh terutama dengan industri pengolahan lainnya seperti tampak pada Gambar 4, 5 dan 6.

Selanjutnya bila perbedaan ketinggian kolom economic landscape MPM tersebut dilihat untuk masing-masing sektor (Tabel 4), sama seperti yang terdapat pada transaksi domestik maka untuk transaksi total juga dapat dibedakan menjadi dua kecenderungan peningkatan ketinggian kolom economic landscape MPM. Pertama, sektor-sektor yang memiliki kecenderungan variasi ketinggian kolom economic landscape MPM selama periode analisis yang meningkat dengan peningkatan yang bertambah, yaitu: industri pengolahan dan pengawetan ikan, industri pengeringan dan penggaraman ikan, jasajasa dan lainnya, perikanan laut dan perikanan darat. Kedua, sektor-sektor yang memiliki kecenderungan variasi ketinggian kolom economic landscape MPM selama periode analisis meningkat namun dengan peningkatan yang cenderung menurun, yaitu: industri pengolahan hasil pertanian non perikanan, industri pengolahan lainnya, pertanian non perikanan dan pertambangan dan galian.

Dari perbedaan kecenderungan variasi ketinggian kolom economic landscape MPM tersebut (Gambar 4, 5 dan 6 serta Tabel 3 dan 4), sektor-sektor perikanan primer dan perikanan sekunder memiliki variasi ketinggian kolom economic landscape MPM yang cenderung meningkat dengan peningkatan yang bertambah. Pada periode tahun 1990-1995 untuk perikanan sekunder masing-masing meningkat sebesar 22,79\% untuk industri pengolahan dan pengawetan ikan, dan sebesar $29,90 \%$ untuk industri pengeringan dan penggaraman ikan; dan untuk perikanan primer masing-masing 
Tabel 4. Perbedaan Perubahan Variasi Ketinggian Kolom "Economic Landscape" dari MPM antara Transaksi Total dengan Transaksi Domestik dari Sektor-Sektor dalam Perekonomian Indonesia, Tahun 1990-2000

Table 4. Column Height Variance Change of Economic Landscape from MPM between Total Transaction to Domestic Transaction from Indonesian Economy Sectors during 19902000

\begin{tabular}{|c|c|c|}
\hline \multirow{2}{*}{$\begin{array}{l}\text { Kecenderungan Arah Perubahan } \\
\text { Ketinggian Kolom economic landscape } \\
\text { MPM / Trend of Column Height Change } \\
\text { Path of MPM Economic Landscape }\end{array}$} & \multicolumn{2}{|c|}{ Sektor / Sector } \\
\hline & $\begin{array}{c}\text { Transaksi Total / Total } \\
\text { Transaction }\end{array}$ & $\begin{array}{l}\text { Transaski Domestik / } \\
\text { Domestic Transaction }\end{array}$ \\
\hline $\begin{array}{l}\text { A. Perubahan meningkat dengan } \\
\text { kecenderungan peningkatan yang } \\
\text { bertambah*)/Increasing Change with } \\
\text { Increasing Trend*) }\end{array}$ & $(6),(5), 9,2,(3)$ & (6), (5), 1, (3) \\
\hline $\begin{array}{l}\text { B. Perubahan meningkat dengan } \\
\text { kecenderungan peningkatan yang } \\
\text { berkurang }{ }^{* *} / \text { /Increasing Change with } \\
\text { Decreasing Trend }{ }^{* *} \text { ) }\end{array}$ & $(7),(8), 1,(4)$ & $(7),(8), 9,2,(4)$ \\
\hline
\end{tabular}

Sumber: Diolah Berdasarkan Hasil Perhitungan dari Lampiran 1 dan 2.

Source: Extracted from calculation in Appendix 1 and 2

Keterangan/ Remarks:

- *) Variasi ketinggian kolom economic landscape MPM meningkat pada periode 1990-1995 dan kembali meningkat pada periode 1995-2000 dengan peningkatan yang semakin bertambah/ Column height variation of MPM economic landscape is increasing during 1990-1995 and tends to increase more in 1995-2000 with increasing trend

-**) Variasi ketinggian kolom economic landscape MPM meningkat pada periode 1990-1995 dan kembali meningkat pada periode 1995-2000 namun dengan peningkatan yang semakin berkurang/ Column height variation of MPM economic landscape is increasing during 1990-1995 and tends to increase more in 1995-2000, but with decreasing trend

- Sektor ( ) menunjukkan sektor dengan arah perubahan yang konsisten antara periode 19901995 dan periode 1995-2000/ sector () describe the consistent change during 1990-1995 and 1995-2000

- Sektor-1/ Sector-1 = sektor pertanian non perikanan/ Non-Fisheries Agriculture Sector

- Sektor-2/ Sector-2 = sektor perikanan laut dan hasil perairan laut lainnya/ Marine Fisheries and Other Marine Fisheries Product Sector

- Sektor-3/ Sector-3 = sektor perikanan darat dan hasil perairan darat lainnya/ Inland fisheries and other inland fisheries product sector

- Sektor-4/ Sector-4 = sektor pertambangan dan galian/ Quarrying and Mining Sector

- Sektor-5/ Sector-5 = sektor industri pengeringan ikan dan biota perairan lainnya/ Dried and Salted Processing Industry

- Sektor-6/ Sector-6 = sektor industri pengolahan dan pengawetan ikan dan biota perairan lainnya/ Processing and Preserving Industry

- Sektor-7/ Sector-7 = sektor industri pengolahan hasil pertanian non perikanan/ NonFisheries Agriculture

- Sektor-8/ Sector-8 = sektor industri pengolahan lainnya/ Other Processing Industry

- Sektor-9/ Sector-9 = sektor jasa-jasa dan lainnya/ Other Services 
sebesar 23,51\% untuk perikanan laut dan sebesar 44,05\% untuk perikanan darat. Selanjutnya pada periode 1995-2000 kembali meningkat dengan peningkatan yang lebih besar, yaitu sebesar $71,71 \%$ untuk industri pengolahan dan pengawetan ikan dan sebesar $31,76 \%$ untuk industri pengeringan dan penggaraman ikan; dan sebesar $29,02 \%$ untuk perikanan laut dan sebesar $45,48 \%$ untuk perikanan darat.

Bila dibandingkan antara transaksi total dengan transaksi domestik kecenderungan variasi ketinggian kolom economic landscape MPM dari sektor-sektor perikanan primer dan perikanan sekunder tersebut, ternyata untuk industri pengeringan dan pengolahan ikan, industri pengolahan dan pengawetan ikan, dan perikanan darat memiliki arah perubahan yang cenderung meningkat dengan peningkatan yang semakin besar baik pada transaksi total maupun transaksi domestik. Sedangkan untuk perikanan laut memiliki kecenderungan yang berbeda, yaitu menunjukkan arah perubahan yang cenderung meningkat dengan peningkatan yang semakin besar pada transaksi total, sementara untuk transaksi domestiknya justru cenderung meningkat dengan peningkatan yang berkurang (Tabel 4). Kondisi ini menunjukkan bahwa dari sektor-sektor yang terkait dengan perikanan tersebut, ternyata hanya perikanan laut yang memiliki kekuatan ekonomi domestik yang cenderung melemah. Namun demikian secara keseluruhan dari sektor-sektor yang terkait dengan perikanan (baik primer maupun sekunder) ternyata masih menunjukkan ketergantungannya terhadap penggunaan input faktor yang berasal dari luar negeri yang cenderung meningkat selama periode analisis (19902000).

\section{KESIMPULAN DAN IMPLIKASI KEBIJAKAN \\ Kesimpulan}

Berdasarkan kecenderungan rata-rata ketinggian nilai Multiplier Product Matrix
(MPM) sektor perikanan pada "economic landscape" transaksi domestik yang cenderung meningkat selama periode analisis (1990-2000), diperoleh indikasi bahwa secara struktural keterkaitan sektor perikanan (kecuali perikanan laut) mengalami perubahan yang meningkat dengan sektor-sektor lainnya dalam perekonomian Indonesia, meskipun untuk perikanan laut masih cenderung menurun. Secara implisit indikasi tersebut ditunjukkan oleh derajat keterkaitannya dari kekuatan ekonomi domestik dengan sektorsektor lainya dalam perekonomian Indonesia yang berubah menjadi semakin baik (meningkat).

Di sisi lain, sebagaimana ditunjukkan oleh rata-rata ketinggian nilai MPM sektor perikanan pada economic landscape transaksi total yang secara relatif cenderung lebih besar dibandingkan transaksi domestiknya, diperoleh indikasi bahwa perubahan struktur keterkaitan sektor perikanan tersebut masih diikuti oleh penggunaan impor barang yang semakin meningkat dalam proses produksinya. Dengan kata lain, perubahan struktur keterkiatan sektor perikanan dengan sektor-sektor lainnya dalam perekonomian Indonesia yang meningkat selama periode analisis ternyata belum mampu menghilangkan ketergantungannya terhadap penggunaan input faktor yang berasal dari luar negeri.

\section{Implikasi Kebijakan}

Adanya indikasi bahwa secara struktural keterkaitan sektor perikanan mengalami perubahan yang meningkat dengan sektorsektor lainnya dalam perekonomian Indonesia, namun dalam perkembangan proses produksinya masih belum mampu menghilangkan ketergantungannya terhadap penggunaan input faktor yang berasal impor. Untuk itu, dukungan pemerintah dalam memberikan berbagai kemudahan terhadap kegiatan usaha perikanan agar mampu memperkuat daya tahan ekonomi domestiknya melalui penggunaan 
sumberdaya domestik secara optimal dan mengurangi secara bertahap penggunaan bahan impor, serta meningkatkan derajat keterkaitannya baik ke depan maupun ke belakang dengan sektor-sektor lainnya dalam perekonomian Indonesia. Selain itu, dipandang penting untuk mengefektifkan kembali penerapan kebijakan dan strategi substitusi impor (inword looking policy and strategy) bagi pengembangan sektor usaha di sektor perikanan ke depan.

\section{DAFTAR PUSTAKA}

Adelman, I. 1984. "Beyond Export Leg Growth". World Development Report. Vol. 12. No. 9.

Akita, T. 1991, Industrial Structure and The Sources of Industrial Growth in Indonesia: An I-O Analysis Between 1971 and 1985, Asian Economic Journal vol. 5, Vol. 2: 139-158.

Akita, T. 1992. Sources of Regional Economic Growth in Japan: A Case of Hokkaido Prefecture between 1970 and 1985. Journal of Applied Input Output Analysis, 1:88-107.

Akita, T. 1994. Interregional Interdependence and regional Economic Growth in Japan: An Input-Output Analysis. International Regional Science Review, 16, No. 3: 231248.

Badan Pusat Statistik. 2000. Kerangka teori dan Analisis Tabel Input-Output. Biro Pusat Statistik. Jakarta.

Badan Pusat Statistik. 2004a. Tabel InputOutput Indonesia 2000. Jilid I, II dan III. Badan Pusat Statistik. Jakarta.

Badan Pusat Statisitik. 2004b. Indikator Ekonomi Makro Sektor Kelautan dan Perikanan Tahun 1990 - 2000. Buku I. Badan Pusat Statistik. Jakarta.

Bell, C. and P. Hazell, 1980. Measuring the Inderect Effects on An Agricultural Investment Project on its Surrounding Region. AJAE, 65: 75-86.

Berry, A. 1995. The Contribution of Agricultural to growth: Colombia in Agricultural on the
Road to Industrialization. J.W. Mellor. Ed. The John Hopkins University Press London.

Bhalla, G.S. 1995. Agricultural Growth and Industrial Development in Punjab. In Agricultural on the Road to Industrialization. J.W. Mellor ed. The John Hopkins University Press London.

Bigsten, A. and P.Collier, 1995. Linkages From Agricultural Growth in Kenya. In Agricultural on the Road Industrialization. J.W. Mellor ed. The John Hopkins University Press London.

Biro Pusat Statistik. 1994. Tabel Input-Output Indonesia 1990. Jilid I, II dan III. Biro Pusat Statistik. Jakarta.

Biro Pusat Statistik. 1999. Tabel Input-Output Indonesia 1995. Jilid I, II dan III. Biro Pusat Statistik. Jakarta.

Cavallo, D. and Y.Mundlak, 1982. Agriculture and Economic Growth in An Open Economy: The Case of Argentina. IFRI. Research report 35, Washington, D.C.

Celes, R. and E.Lizano, 1995. Develompent in Costa Rica: The Key Role of Agricultural, In Agricultural on the Road to Industrialization. J.W. Mellor. Ed. The John Hopkins University Press London.

Chenery, H.B. 1980. Interaction between Industrialization and Exports. American Economic Review, 70: 281-87.

Chenery, H.B., Robinson, S., and M.Syrquin, 1986. Development Patterns: Among Countries and Overtime, Review of Economic and Statistics, November 1968, 50, pp. 416-391.

Commission of European Communities. 1993. System of National Accounts. In Statistique Canada (2001). A Guide to Deflating the Input-Output Accounts: Sources and Methods. Catalogue No. 15F0077GIE, System of National Accounts. Ottawa, Ontario. http://www.stacan.ca. E-mail: nmiller@statcan.ca.

Dahuri, R. 1999a. Membangun Kembali Perekonomian Nasional Melalui 
Pembangunan Perikanan dan Kelautan Secara Optimal dan Berkelanjutan: Masukan untuk GBHN 2000, Naskah Akademik Usulan Departemen Perikanan dan Kelautan, IPB, disampaikan kepada Sembilan Fraksi MPR-RI Sidang Umum MPR-RI 1999, PKSPL-IPB, Bogor.

Dahuri, R. 1999b. Visi dan Arah Pembangunan Kelautan Indonesia Memasuki Abad 21. Seminar Kelautan. Departemen Pekerjaan Umum, Jakarta, Juni 1999.

Departemen Kelautan dan Perikanan. 2005a.

Pelaksanaan Pembangunan Kelautan dan Perikanan dalam Satu Tahun Kabinet Indonesia Bersatu. Departemen Kelautan dan Perikanan, Jakarta.

Departemen Kelautan dan Perikanan. 2005b.

Scientific Justification Penetapan Sasaran Makro Pembangunan Sektor Kelautan dan Perikanan Tahun 2007. Departemen Kelautan dan Perikanan, Jakarta.

Feldman, S.J., McClain, D., and K.Palmer. 1987. Sources of Structural Change in the U.S., 1963-78: An Input-Output Perspective. Review of Economics and Statistics, vol. 69: 503-510.

Guo, J. and M.A. Planting, 2000, Using InputOutput Analysis to Measure U.S. Economic Structural Change Over a 24 Years Period, Paper, Industry Economic Division, Bereau of Economic Analysis, U.S. Departement of Commerce, Washington.

Haggblade, S. and P. Hazell. 1989. Agricultural Technology and Farm-Non Farm Growth Linkages. Agricultural Economics: 345-364.

Haggblade, S., J. Hammer and P. Hazell. 1991. Modelling Agricultural Growth Multiplier. AJAE, 73: 361-174.

Holland, D. and S.C.Cooke. 1992. Sources of Structural Change in the Washington Economy: An Input-Output Prespective. The Annals of Regional Science, 26: 155170.
James, W.E., and N. Fujita. 1989. Import Substitution and Export Promotion in the Growth of the Indonesain Industrial Sektor. ASEAN Ecomoic Bulletin 6, no. 1: 59-70.

Jhingan, M.L. 1991. Ekonomi Pembangunan dan Perencanaan. Edisi ke delapan, RajaGrafindo Persada, Jakarta.

Johnston, B.F. and P. Kilby. 1975. Agriculture and Structureal Transformation: Economic Strategies in Late Developing Countries, Oxford University Press, London.

Kaneko, Y. 1984. Price Deflator in InputOutput Tabel: Its Formulation and Its Application. A Quantitative Study on the Medium/Long-Term Prospects of the Indonesian Economy. Bappenas. Ocassional Paper Series No. 45, Agustus 1984.

King, R.P. and D. Byerlee, 1978. Factor Intensities and Locational Linkages of Rural Consumption Patterns in Sierra Leone, American Journal of Agricultural Economic, Vol. 60, No. 2.

Kubo, Y., Robinson, S., and M. Syrquin. 1986. The Methodology of Multisector Comparative Analysis. In Industrialization and Growth: $A$ Comparative Study, ed. by Chenery, H.B., Robinson, S., and Syrquin, M. New York: Oxford University Press.

Kusumastanto, T. 2002. Reposisi "Ocean Policy" dalam Pembangunan Ekonomi Indonesia di Era Otonomi Daerah. Orasi IImiah: Guru Besar tetap Bidang IImu kebijakan Ekonomi Perikanan dan Kelautan, Fakultas Perikanan dan IImu Kelautan, Institut Pertanian Bogor 21 Sepetember 2002. Institut Pertanian Bogor. Bogor. 134 halaman.

Lee, C. and G. Schluter. 1993. Growth and Structural Change in U.S. Food and Fiber Industries: An Input-Output Perspective. American Journal of Agricultural Economics, 75, no. 3: 666-73. 
Liu, A. and D.S. Saal. 2000, Sources of Structural Change and Output Growth of South Africa's Economy : 1975-1993, Paper, Middlesex University Business Schooll.

Martin, R.P., and D Holland. 1992. Sources of Output Change in the U.S. Economy. Growth and Change, 23, no. 4: 446-68.

Mellor, J.W., and U Lee. 1973. Growth Linkages of the New Food Grain Technologies. Indian Journal of Agricultural Economics, vol. 28, no. 1.

Mellor, J.W. 1986. Agriculture on the Road to Industrialization, in John P. Lewis and Valeriana Kallab (eds), Development Strategies Reconsidered, Overseas Development Council, Washington D.C.

Mellor, J.W. 1989. The Balance Between Industry and Agriculture, Macmillan, Houndmills.

Mundlak, Y. and R. Donenech. 1995. Agricultural Growth in Argentina. In Agricultural on the Road Industrialization. Mellor, J.W. ed. The John Hopkins University Press London.
Nazara, S. 1997. Analisis Input Output. Lembaga Penerbit Fakultas Ekonomi Universitas Indonesia. Jakarta. 130 halaman.

Nazara, S., Dong G., Geoffrey J.D.H., and D. Chokri. 2004. Input-Output Analysis with Python. Regional Economics Applications Laboratory. University of Illinois at Urbana-Champaign.

Rangrajan, C. 1982. Agricultural Growth and Industrial Performance in India. IFPRI. Research Report, 33. Washington, D.C.

Soni's, M., Hewings, G.J.D., and J. Guo. 1996. Sources of Structural Change in OutputOutput Systems: A Field of Influences Approach. Economic Systems Research, 8: 15-32.

Sumodiningrat, G. dan M. Kuncoro. 1990, Strategi Pembangunan Pertanian dan Industri: Mencari Pola Simbiosis, Prisma, No. 2, Tahun XIX.

Urata, S. 1987. Sources of Economic Growth and Structural Change in China: 19561981. Journal of Comparative Economics, 11: 96-115. 


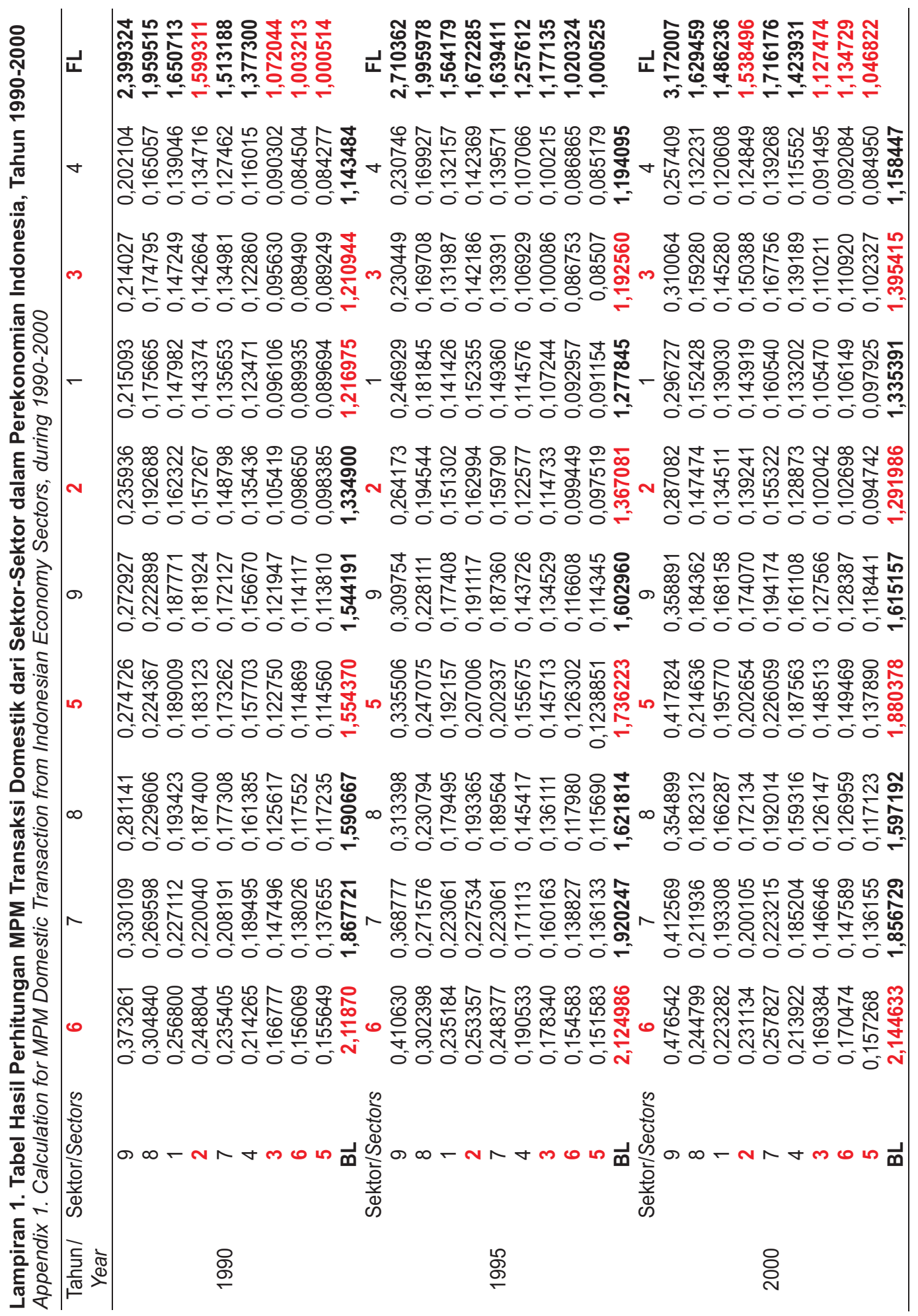

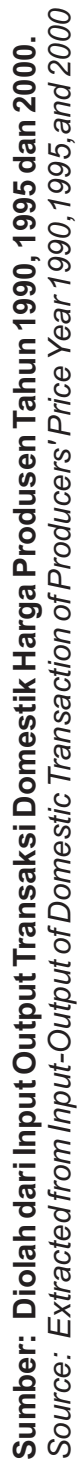


Keterangan/Remarks :

- Sektor-1/ Sector-1 = sektor pertanian non perikanan/ Non-Fisheries Agriculture Sector

- Sektor-2/ Sector-2 = sektor perikanan laut dan hasil perairan laut lainnya/ Marine Fisheries and OtherMarine Fisheries Product Sector

- Sektor-3/ Sector-3 = sektor perikanan darat dan hasil perairan darat lainnya/ Inland Fisheries and otherlnland Fisheries Product Sector

- Sektor-4/ Sector-4 = sektor pertambangan dan galian/ Quarrying and mining sector

- Sektor-5/ Sector-5 = sektor industri pengeringan ikan dan biota perairan lainnya/ Dried and salted Processing Industry

- Sektor-6/Sector-6 = sektor industri pengolahan dan pengawetan ikan dan biota perairan lainnya/ Processing and Preserving Industry

- Sektor-7/Sector-7 = sektor industri pengolahan hasil pertanian non perikanan/ NonFisheries Agriculture

- Sektor-8/Sector-8 = sektor industri pengolahan lainnya/Other Processing Industry

- Sektor-9/Sector-9 = sektor jasa-jasa dan lainnya/Other Services 